Vol. 24, No. 3, Juli 2021, hlm. 571-580

p-ISSN: 1410-9344; e-ISSN: 2549-5631

WARTA LPM

homepage: http://journals.ums.ac.id/index.php/warta

\title{
Literasi Berpikir Kreatif dan Pengenalan Program Santripreneur di Pesantren Miftahul Jannah
}

\author{
${ }^{1}$ Gatot Iwan Kurniawan, ${ }^{2}$ Dani Dagustani \\ Sekolah Tinggi Ilmu Ekonomi Ekuitas \\ Email: 'gatot.iwan@ekuitas.ac.id, ${ }^{2}$ dagustani23@gmail.com
}

\section{Article Info}

Submitted: 21 November 2020

Revised: 12 April 2021

Accepted: 1 July 2021

Published: 20 July 2021

Keywords: Training, Creative Idea, entrepreneurship
Kata kunci: Pelatihan; Ide Kreatif; Kewirausahaan

\section{Abstract}

The community service activities aim to introduce a new learning method with different teaching patterns at Miftahul Jannah Islamic Boarding School. A rigid, monotonous and one-way learning system is one of the causes of learning that does not encourage children to have critical thinking skills. The material is in the form of an exciting program that combines theory and games to open up insight and direct children to think creatively. In addition, the introduction of the entrepreneurship program will strengthen how the practice of a creative idea can provide exciting ideas in the creation or development of business products. The measurement of the success rate of training uses a four-level model to evaluate activity consisting of reactions, learning, behaviour, and results. The measurement results show that the movement was successful based on the indicators filled in by the participants. Calculation of pre-test and post-test showed a significant increase in knowledge by $62 \%$ of the total participants, $26 \%$ offered a rise. Still not substantial, the remaining $12 \%$ showed no gain and no decrease. Based on observations within one week, the students have started trying to apply creative thinking patterns when they carry out the learning process by the teachers in the pesantren environment. In addition, the results of the evaluation by the team through discussion showed a change in the way they analyzed a problem and interpreted it in different ways.

Abstrak
Kegiatan pengabdian pada masyarakat yang dilakukan bertujuan
untuk memperkenalkan suatu metode pembelajaran yang baru
pola pengajaran yang berbeda di Pesantren Miftahul Jannah. Sistem
pembelajaran yang kaku, monoton, dan satu arah merupakan salah
satu penyebab pembelajaran kurang mendorong anak untuk memiliki
kemampuan berpikir kritis. Materi berupa program menarik yang
memadukan antara teori dan permainan dengan maksud untuk
membuka wawasan dan mengarahkan anak agar mampu berpikir


kreatif. Selain itu, pengenalan program kewirausahaan akan memperkuat bagaimana praktik dari suatu ide kreatif dapat memberikan suatu ide-ide menarik dalam penciptaan atau pengembangan produk usaha. Pengukuran tingkat keberhasilan pelatihan menggunakan model empat tingkat untuk mengevaluasi pelatihan yang terdiri dari reaksi, pembelajaran, perilaku, dan hasil. Hasil pengukuran menunjukkan bahwa pelatihan berhasil berdasarkan isian indikator dari peserta. Perhitungan pre-rest dan post-test, menunjukkan peningkatan pengetahuan secara signifikan sebesar $62 \%$ dari total peserta, $26 \%$ menunjukkan peningkatan tapi tidak signifikan, sisanya sebesar $12 \%$ menunjukkan tidak ada peningkatan dan tidak ada yang mengalami penurunan. Berdasarkan pengamatan dalam waktu satu minggu para santri sudah mulai mencoba menerapkan pola berpikir kreatif ketika mereka malakukan proses pembelajaran oleh para pengajar di lingkungan pesantren. Selain itu hasil evaluasi oleh tim melalui diskusi memperlihatkan adanya perubahan cara mereka menganalisis suatu permasalahan dan mengintepretasikannya dengan berbagai cara yang berbeda.

\section{PENDAHULUAN}

Dengan meningkatnya pendidikan anak pada dasarnya untuk meningkatkan pengembangan pola pikir yang lebih baik, diantaranya yaitu anak mampu untuk berpikir kritis dalam memecahkan serta menyelesaikan suatu permasalahan yang disertai dengan cara berkomunikasi dengan baik. Sistem pembelajaran yang kaku, monoton, dan satu arah merupakan salah satu penyebab pembelajaran kurang mendorong pada kemampuan berpikir kritis. Melihat pada rancangan kurikulum yang terlalu luas, bisa menjadi penyebab anak berpikir hanya untuk menyelesaikan materi yang mereka dapatkan daripada belajar untuk berpikir secara analitis. Padahal, berpikir analitis merupakan salah satu cara bagi mereka untuk bisa berpikir kreatif. Pengembangan kreativitas adalah bagian penting dari desain kurikulum dan komponen penting dalam keberhasilan siswa (Black et al., 2015). Teknik mengajar yang salah dapat menyebabkan anak kurang terangsang untuk berpikir kreatif. Susanto (2013), menjelaskan bahwa berpikir kreatif adalah proses dengan menerapkan orisinalitas, kelancaran, fleksibilitas, dan elaborasi. Berpikir kreatif merupakan kemampuan mengembangkan ide yang tidak biasa, berkualitas, dan sesuai tugas (Sani, 2014). Individu yang mendapat nilai tinggi pada tes kemampuan berpikir kreatif akan mampu menghasilkan ide-ide divergen atau orisinal dalam berbagai domain (Hong \& Milgram, 2010). Berpikir kreatif bisa dikembangkan dalam berbagai aspek masalah untuk di pecahkan. Beberapa peneliti berpendapat bahwa kemampuan berpikir kreatif adalah domain umum dan spesifik (Plucker \& Zabelina, 2009).

Di indonesia sendiri kurikulum ada yang memiliki konsep yang kurang mengarahkan anak untuk dapat berpikir kreatif, sehingga akan sangat membantu jika diberikan suatu pengetahuan di luar pembelajaran mereka di sekolah. Santrock, (2011) Menjelaskan berpikir adalah memanipulasi atau mengelola dan mentransformasikan informasi dalam memori. Berpikir kreatif banyak memberikan dampak positifbagipelajardalammasaperkembangannya. Dampak positif yang didapatkan yaitu orang menampilkan lebih banyak kreativitas dalam pemecahan masalah, meningkatkan kinerja mereka dalam tugas-tugas pemecahan masalah (Estrada et al., 1994). Pengaruh positif juga ditemukan untuk meningkatkan kompleksitas dan fleksibilitas kategorisasi mental (FernándezAbascal \& Díaz, 2013). Kreativitas dalam serangkaian tugas, membuat beberapa peneliti menyimpulkan bahwa afek menyenangkan mendorong pemikiran orisinal (Lyubomirsky et al., 2005). Permasalahan disini yaitu kurang 
adanya pengetahuan bagi siswa untuk mampu mengembangkan kemampuan mereka untuk berpikir kreatif dan kritis mengingat banyaknya materi yang disyaratkan oleh kurikulum yang ada. Alternatif penambahan pengetahuan di perlukan untuk bisa memberikan pengetahuan secara maksimal melalui pemahaman dan penerapan untuk berpikir kreatif.

Adanya peluang untuk bisa memberikan suatu konstrubusi dari perguruan tinggi dalam bentuk pelatihan sebagai tambahan materi pembelajaran yang akan fokus pada pola anak remaja untuk bisa berpikir kreatif, menjadi suatu dasar dalam pelaksanaan pengabdian kepada masyarakat ini. Berpikir kreatif merupakan hal yang menarik perhatian tidak hanya bagi para ahli pendidikan, tetapi juga bagi masyarakat luas (Craft, 2003). Dosen-dosen STIE Ekuitas akan menyiapkan dan melaksanakan suatu pelatihan sederhana mengenai topik-topik menarik diantaranya bagaimana untuk berpikir kreatif. Objek dari pengabdian pada masyarakat yaitu para santri yang ada di Pesantren Miftahul Jannah, dengan peserta yaitu siswa Sekolah Menengah Pertama (SMP) dan Sekolah Menengah Atas (SMA). Pesantren beralamat di Jl. Rancakendal Luhur Kp Sekepicung, RT.02/ RW.05, Ciburial, Kecamatan Cimenyan, Bandung, Jawa Barat, Kode Pos 40198, Indonesia. Posisi pesantren di peta dapat dilihat pada gambar 1. Selain materi mengenai berpikir maka akan diberikan juga materi mengenai kewirausahaan masif. Program kewirausahaan saat ini mulai banyak dikembangkan diberbagai perguruan tinggi di Indonesia, baik menjadi Program Studi
(Prodi), konsentrasi, dan inkubator bisnis. Tingginya minat mahasiswa mengikuti program kewirausahaan, serta dukungan berbagai pihak terhadap dunia usaha, khususnya usaha mikro kecil menengah, mendorong banyak pihak tak terkecuali mahasiswa memilih untuk berkarir menjadi wirausaha.

Data menunjukkan bahwa masih kurangnya minat masyarakat untuk berwirausaha, sehingga untuk mengatasi permasalahan tersebut pemerintah, perguruan tinggi, dan para praktisi bisnis terus berupaya bersinergi untuk menciptakan wirausaha mandiri berbasis ilmu pengetahuan dan teknologi di lingkungan mahasiswa. STIE Ekuitas saat ini sedang mengembangkan suatu program Kewirausahaan Masif yang dikemas dengan bentuk materi yang menarik, kaya akan permainan diskusi kelompok, praktik langsung juga mengkaitkan dengan media online untuk sarana praktek mereka. Hasil dari program ini memberikan dampak yang cukup signifikan kepada mahasiswa yang ada di kampus. Pada mahasiswa mampu untuk membuat konten-konten menarik dalam mempresentasikan produk mereka berdasarkan teknik yang yang diajarkan. Selain itu, terbentuk kerjasama tim karena materi ini mengandung muatan kebersamaan yang terus mereka lakukan selama satu semester. Mahasiswa mampu untuk berbicara di depan umum, bahkan meng-upload presentasinya di media sosial. Untuk meningkatkan mutu dari perguruan tinggi program baru tersebut merupakan salah satu pengembangan strategi dalam menciptakan atmosfer kewirausahaan di lingkungan kampus.

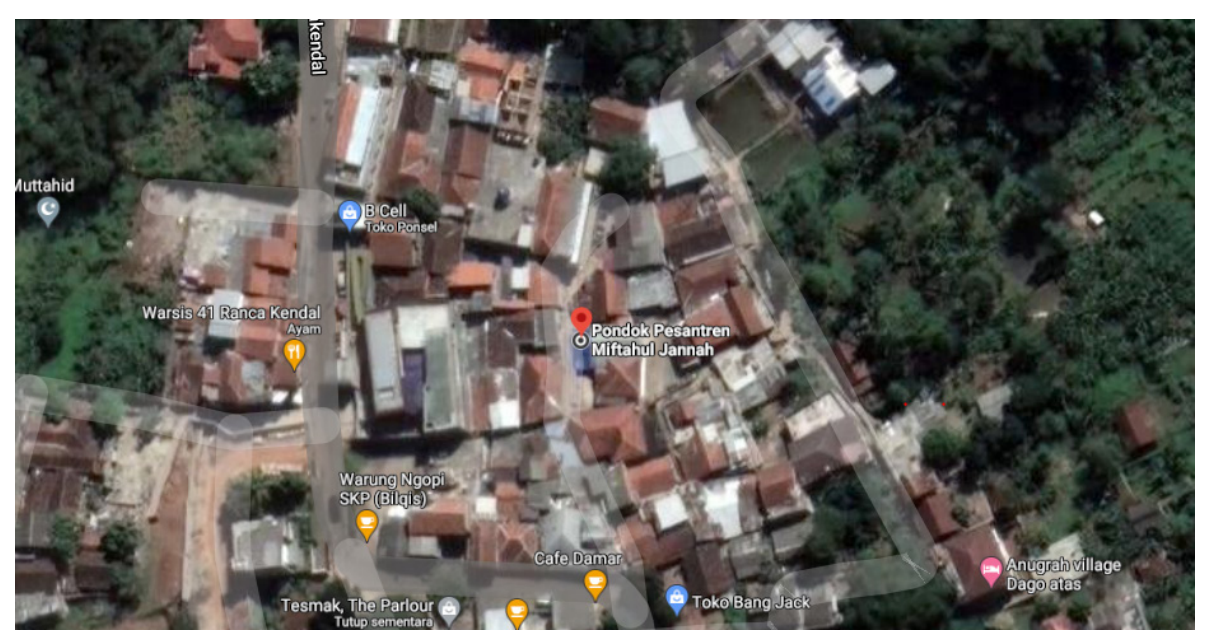

Gambar 1. Posisi Pesantren Miftahul Jannah pada Peta 
Kampus yang merupakan pusat dari kajian teori, maka sudah selayaknya menyebarkan pengetahuan kepada masyarakat agar penyebaran ilmu pengetahuan dan teknologi bisa dengan cepat tersebar yang tidak harus selalu dilaksanakan di kampus. Melihat balik ke sejarah, Pondok Pesantren berperan penting dalam perjuangan kemerdekaan dan pembangunan, dengan melahirkan tokoh-tokoh yang memperjuangkan bangsa ini. Tempat ini juga menghasilkan pemimpin-peminpin yang memiliki akhlak baik. Pondok pesantren merupakan sarana yang mampu mendukung pembangunan bagi santri khususnya maupun masyarakat pada umumnya. Pentingnya peran pondok pesantren harus terus didukung baik itu oleh pemerintah, masyarakat, serta dunia akademisi, sehingga tempat ini terus lestari dan diharapkan akan menghasilkan generasi muda yang mampu menjadi salah satu penopang, untuk mengembangkan bangsa ini. Heilbrunn (2010), mengungkapkan, pendidikan kewirausahaan sejak usia dini memberikan hasil yang lebih baik. Dengan meningkatkan literasi pengetahuan akan mampu meningkatkan kemampuan para santri agar melihat juga pola perkembangan pendidikan saat ini. Menurut Menteri Perindustrian Pesantren memiliki peranan penting dalam proses pembangunan. Pemerintah juga berupaya untuk terus melakukan kegiatan yang mengikutsertakan pondok pesantren dalam kegiatan yang bisa meningkatkan perekonomian masyarakat. Salah satunya dengan menggabungkan konsep pesantren dengan entrepreneur yang digabung menjadi program santripreneur.

Para santri merupakan bagian dari generasi mudayangakanmeneruskanpembangunan,tentu harus mampu mengikuti perkembangan yang demikian cepat. Dengan memperkenalkannya program dari kampus ini kepada santri, diharapkan akan memberikan gambaran suatu bentuk kegiataan kewirausahaan yang menarik dan juga sebagai materi lanjutan dari berpikir kreatif, karena bagi seorang wirausaha, berpikir kreatif merupakan salah satu syarat komponen yang harus mereka miliki ketika mereka terjun ke dunia usaha. Dari santri, diharapakn akan memberikan konstribusi kepada masyarakat sekitar karena sebagaian besar peserta santri berdomisili disekitar pesantren.

\section{METODE}

Proses perencanaan serta pelaksanaan pelatihan akan dilakukan dengan mengacu pada gambar 2 .

\section{Uraian kegiatan Pelaksanaan Pelatihan}

a. Tahap awal yang dilakukan tim yaitu survei kondisi mitra untuk mengetahui secara jelas kondisi mitra, berkenaan dengan kondisi pesantren,berkaitan dengan pengetahuan mereka saat itu terhadap materi yang akan diberikan, dan menentukan tempat yang dilaksanakannya pelatihan. Pada tahap ini tim berkunjung terlebih dahulu ke pimpinan pesantren, kemudian diadakan diskusi dengan para tenaga pengajar yang ada, dengan maksud untuk mengetahui sejauh mana hubungan antara materi yang akan diberikan dengan pengetahuan yang sudah diajarkan kepada para santri. Proses ini dilakukan agar tidak terjadi duplikasi kegiatan yang akan menyebabkan program tidak memberikan manfaat yang maksimal. Setelah diskusi maka tim melakukan survei ruangan untuk bisa memperkirakan kondisi saat akan dilakukan pelatihan.

b. Dari hasil survei yang dilakukan pada tahap satu, maka tim sudah mendapatkan data, diantaranya kelayakan materi yang akan diberikan dan tempat pelaksanaan pelatihan. Dari data didapatkan, bahwa materi yang direncanakan sejak awal yang akan diberikan bisa diterapkan karena materi tersebut masih belum mereka dapatkan. Sedangkan untuk tempat pelatihan sudah diputuskan dilakukan di pesantren tersebut dengan menggunakan pelataran masjid. Untukjadwal pelatihannya dilakukan dua kali dengan materi yang berbeda. Pertama yaitu tentang literasi berpikir kreatif dan materi berikutnya tentang kewirausahaan. Sedangkan untuk jadwal perlaksanaan dilakukan dari pukul 09.00 pagi hingga pukul 16.00. Pertemuan dilakukan dua kali dengan selang waktu satu minggu antara pertemuan pertama dan yang kedua. Pada tahap ini yang harus diperhatikan yaitu sudah diputuskan mengenai tempat pelatihan dan materi apa saja yang akan diberikan oleh pihak pemberi materi. 


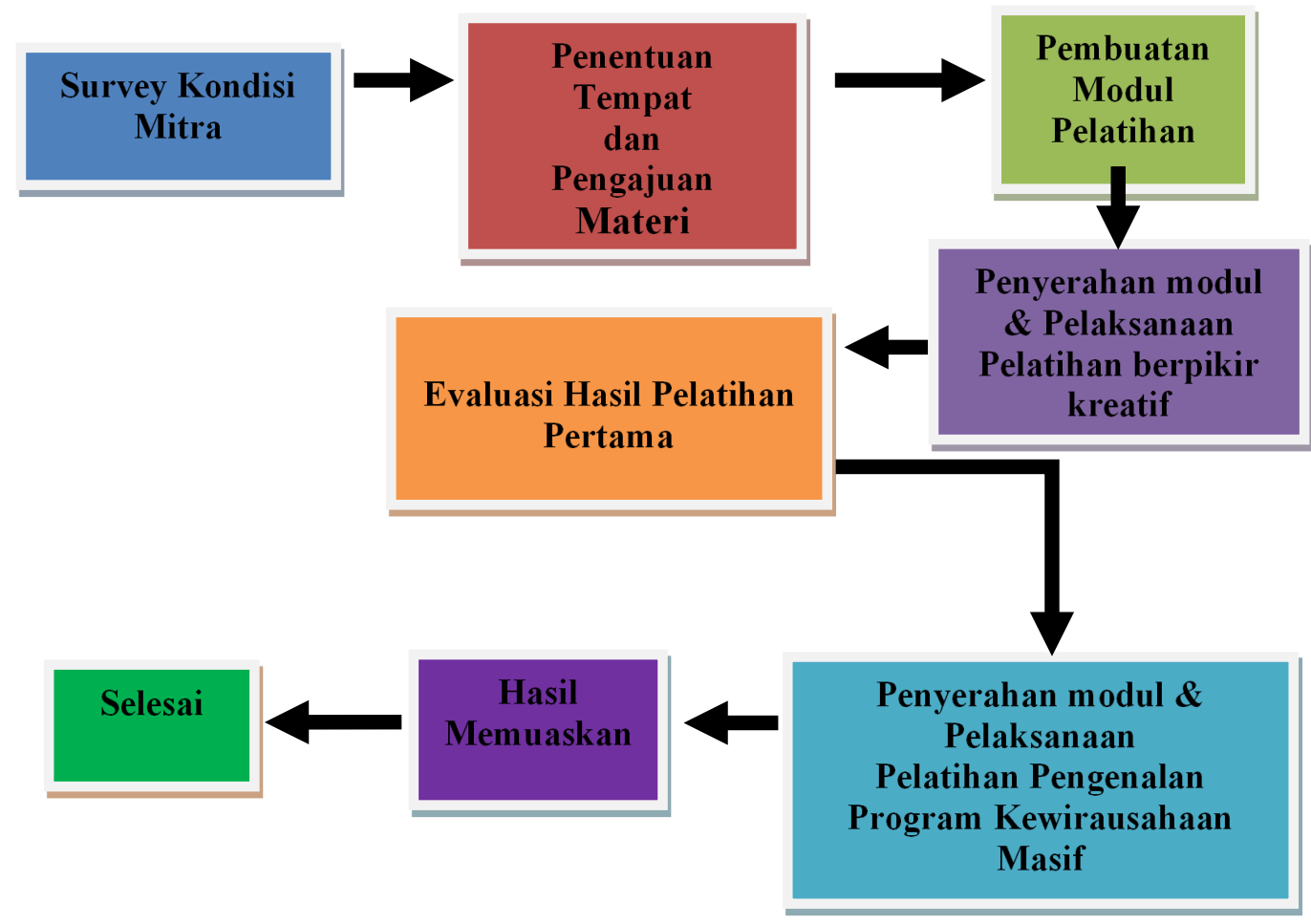

Gambar 2. Proses Pelaksanaan Pelatihan Berpikir Kreatif dan Pengenalan Program Kewirausahaan Masif

c. Pembuatan modul pelatihan, dimana pada tahap ini modul akan dibuat dengan format yang sederhana sehingga akan mudah dipahami oleh para peserta pelatihan. Bahan pelatihan akan disusun dengan menggunakan buku-buku, terkait yang akan dibeli sebelumnya dan dilengkapi dengan bahan-bahan yang akan didapat melalui internet dan juga pendapat dari para pelaku yang disusun secara sistematis untuk bahan pelatihan. Bentuk pelatihan sederhana dengan materi yang sedikit tetapi difokuskan dan dipertajam dalam bentuk permainan yang menarik. Pembuatan modul disesuaikan bahasa dan juga muatannya karena peserta yang mengikuti pelatihan terdiri dari santri yang bersekolah di jenjang Sekolah Menengah Pertama (SMP) dan Sekolah Menengah Atas (SMA), sedangkan materi yang ada diperuntukkan untuk mahasiswa.

d. Pelatihan tahap pertama, pada tahap ini modul yang sudah jadi akan diserahkan kepada peserta pelatihan sebagai acuan pembelajaran dan pada tahap ini juga akan dilakukan kegiatan pelatihan. Kegiatan ini dilakukan sesuai dengan jadwal yang telah ditentukan bersama oleh kedua belah pihak. Materi yang diberikan di pelatihan yang pertama, yaitu tentang literasi berpikir kreatif. Ada 3 muatan ini yang diberikan yaitu memperkenalkan terlebih dahulu pola yang kaku, tanpa mereka sadari telah mereka jalani selama ini. Selanjutnya yaitu memperkenalkan suatu pola berpikir yang baru diluar kebiasaan umum. Dan yang terakhir mengajarkan tentang apa manfaat yang bisa didapatkan dan bagaimana cara membentuk pola baru tersebut.

e. Pada tahap ini akan dilakukan proses evaluasi, untuk melihat sejauh mana dampak dari pemberian materi kepada siswa sehingga akan memberikan suatu masukan dan metode pemberian materi yang akan diterapkan. Pada tahap ini juga sudah menggunakan beberapa indikator pengukuran, untuk menilai sejauh mana penerapan dari pelatihan yang dilakukan pada tahap pertama ini. Penjelasan lebih detail pada proses pengukuran indikator pelaksanaan pelatihan dapat dilihat pada hasil dan pembahasan. Pada evaluasi ini, dilakukan terpisah dengan memberikan isian dan kuesioner bekerja sama dengan 
tenaga pengajar yang ada disana.

f. Pelatihan tahap kedua, pada tahap ini modul yang sudah jadi akan diserahkan kepada peserta pelatihan sebagai acuan pembelajaran dan pada tahap ini juga akan dilakuan kegiatan pelatihan. Kegiatan ini dilakukan sesuai dengan jadwal yang telah ditentukan bersama kedua belah pihak. Pada pelatihan yang kedua ini, sebelum dilaksanakan para santri akan melakukan wawancara ataupun pengisian kuesioner terlebih dahulu, agar didapatkan data-data lanjutan yang sebelumnya sudah dilakukan oleh tenaga pengajar dari pesantren. setelah data didapatkan maka akan lanjut ke materi ke dua tentang kewirausahaan. Materi yang diberikan sangat berkaitan dengan pelatihan yang pertama tentang berpikir kreatif. Santri akan mendapatkan penazaman nalar dengan masukkebeberapa teori untuk menghubungkan antara berpikir kreatif dengan penerapannya di kewirausahaan. Setelah selesai pelatihan maka dilakukan juga pelengkapan data untuk melengkapi indikator yang sudah di rancang sebelumnya.

g. Pada tahap ini pelaksanaan proses pelatihan selesai sesuai dengan hasil yang diinginkan yaitu penyampaian materi dapat diserap oleh para peserta dengan hasil yang memuaskan berdasarkan ukuran indikator yang sudah ditetapkan.

\section{HASIL DAN PEMBAHASAN}

Kegiatan dimulai dengan pemberian materi mengenai Literasi Berpikir Kreatif, materi diberikan dengan metode yang menarik melalui permainan dan interaksi secara lansung dengan peserta, pelaksanaan yang dilakukan tetap mengikuti protokoler yang baik dikarenakan pendemi Covid-19. Dalam pelatihan, materi yang diberikan berupa pemahaman yang secara tidak langsung menuntun peserta untuk bisa berpikir dan menganalisis suatu permasalahan dengan cara pandang yang berbeda, sehingga merangsang mereka untuk berpikir kreatif. Permainan dilakukan dengan maksud untuk memperkuat pemahaman peserta pada materi yang sudah disampaikan. Mereka akan memahami maksudnya dengan memberikan penjelasan di akhir permainan dengan menekankan poin-poin penting.

Setelah pemahaman baru mereka dapatkan, maka cara berpikir kreatif ini coba dikaitkan dengan kewirausahaan. Berpikir kreatif dalam kewirausahaan sudah mutlak harus dikuasai oleh seseorang terutama dalam menciptakan dan mengembangkan suatu usaha. Sama seperti halnya materi yang pertama, materi kedua ini juga dijelaskan melalui permainan, serta pola-pola pikir yang berbeda. Kadang bentuk sederhana bisa memberikan perubahan bagi peserta pelatihan. Pelatihan ini menghasilkan pandangan baru bagi pesertanya, apalagi terlihat bentuk pemahaman mereka yang masih kaku akibat dari pola pengajaran yang monoton dan diterapkan secara turun temurun.

Untuk melihat berhasil atau tidak kegiatan ini maka tim membuat suatu ukuran keberhasilan dengan mempersiapkan indikator pengukuran. Salah satu pendekatan pengukuran untuk melihat tingkat keberhasilan pelatihan yang dikembangkan oleh Kirkpatrick (1996), yang pola pengukurannya menggunakan model empat tingkat untuk mengevaluasi pelatihan yang terdiri dari reaksi (1), pembelajaran (2), perilaku (3), dan hasil (4).

a. Evaluasi tingkat pertama, reaksi, biasanya melibatkan peserta pelatihan yang menyelesaikan evaluasi pasca kursus berkaitan dengan kesan mereka terhadap program yang telah diberikan. Evaluasi pada tahap ini tidak mengukur apa yang telah dipelajari peserta, tetapi mengukur minat, motivasi, dan tingkat perhatian peserta.

b. Tingkat kedua, pembelajaran, melibatkan pengukuran apa yang telah dipelajari peserta baik dari segi pengetahuan dan/ atau keterampilan. Evaluasi pembelajaran dapat mencakup peserta yang berpartisipasi dalam penilaian tertulis atau permainan peran untuk mendemonstrasikan keterampilan mereka.

c. Tingkat ketiga adalah perilaku. Ini melibatkan penilaian kemampuan peserta untuk menggunakan pengetahuan atau keterampilan yang baru mereka pelajari dalam proses mereka belajar atau mencoba menciptakan suatu produk kreatif. 
d. Tingkat keempat, yang dijelaskan sebagai hasil, adalah ukuran dari dampak pelatihan secara keseluruhan.

Berdasarkan model tersebut maka disusun pertanyaan-pertanyaan yang dipersiapkan sebagai bahan evaluasi dan pengisian indikator. Pertanyaan tersebut dirancang sebagai berikut:

a. Reaksi: apakah para santri dapat menerima materi pelatihan dengan baik, apakah teknik penyampaian cukup baik? Apakah sebuah pelatihan dapat direspon dengan baik?

b. Pembelajaran: Apakah para santri mendapatkan pengetahuan dan wawasan yang baru terkait dengan materi yang disampaikan?

c. Perilaku: Apakah para santri dapat menerapkan materi pelatihan dalam kehidupan sehari-hari khususnya dalam pembelajaran?

d. Hasil: Apakah para santri sudah bisa menerapkan pola berpikir kreatif dan mampu mensimulasikan ide pengembangan produk?
Dari pertanyaan-pertanyaan yang ada selanjutnya di buat indikator penilaian yang akan di berikan ke peserta pelatihan. Data di kumpulkan dari pertanyaan yang diberikan melalui tenaga pengajar yang ada di pesantren, data berikutnya dikumpulkan dari kuesioner yang di berikan sebelum pelatihan yang kedua dimulai, data terakhir dikumpulkan ketika santri selesai mengikuti pelatihan yang kedua. Hasil dari indikator yang di tanyakan kepada santri dapat dilihat di tabel 1.

Berdasarkan data yang ada pada tabel 1 . Menunjukkan bahwa hasil pelatihan berhasil dijalankan. Pada data hasil berkaitan dengan keinginan santri untuk menjadi wirausaha ratarata masih ragu-ragu, karena pola pikir peserta pelatihan masih proses pengenalan lebih dalam tentang kewirausahaan itu sendiri, dimana sebelumnya mereka masih berpikir kaku untuk siap berwirausaha. Selain itu hasil dari pengukuran pre-rest dan post-test, menghasilkan data adanya peningkatan pengetahuan secara signifikan sebesar $62 \%$ dari total peserta, $26 \%$ menunjukkan peningkatan tapi tidak signifikan, sisanya sebesar $12 \%$ menunjukkan tidak ada

Tabel. 1. Tabel Indikator Hasil Penilaian

INDIKATOR PENILAIAN HASIL PELATIHAN

\begin{tabular}{clc}
\hline No. & \multicolumn{1}{c}{ INDIKATOR } & HASIL RATA-RATA \\
\hline 1. & Reaction & Sangat Baik \\
& Apakah Materi bisa di terima dengan baik oleh santri? & Sangat Baik \\
& Akah teknik Penyampaian menarik? & Baik \\
& Bagaimana santri merespon terhadap pelatihan? & \\
2. & Learning & ya \\
& Apakah santri mendapat pengetahuan baru dari pelatihan? & ya \\
& Apakah santri mendapatkan pengalaman baru dari pelatihan? & ya \\
Apakah santri tertarik menerapkan apa yang sudah diajarkan? & \\
3. Behavior & ya \\
Apakah santri bisa menerapkan di proses pembelajaran di luar pelatihan? & ya \\
Apakah santri tertarik untuk mencoba berwirausaha? & ya \\
Result & Ragu-ragu \\
& Apakah ada hasil dengan mencoba pola baru dalam belajar? \\
Apakah anda sudah mencoba mengembangkan produk? & ya \\
\hline
\end{tabular}

Sumber: Data diolah 
peningkatan dan tidak ada yang mengalami penurunan.

Hasil pemberian pelatihan mengenai literasi berpikir kreatif dan pengenalan program kewirausahaan masif pada santri yang ada di pondok pesantren, selain dengan menggunakan indikator, tim melihat juga pada interaksi mereka selama pelatihan yang dilakukan. Tes kreativitas merupakan pengukuran atribut kemampuan digunakan untuk melihat kemampuan kognitif misalnya menyusun, menghubungkan, dan menggabungkan beberapa kategori dan berpikir divergen (Cropley, 2000). Ini terlihat karena materi dan permainan yang disajikan memang disusun secara sistematis dan berkesinambungan. Respon mereka akan terlihat pada perubahan cara pandang mereka. Karena pengabdian dilaksanakan oleh tim, maka ada pembagian tugas antara pemberi materi dan anggota timnya yang akan mengamati interaksi dari para santri. Beberapa hal yang menarik dari hasil pelatihan melalui pengamatan tim dan tenaga pengajar didapatkan informasi sebagai berikut:

1. Mereka mulai memahami cara pandang yang monoton yang selama ini mereka terapkan.

2. Mereka memahami tahapan cara berpikir dengan pola yang berbeda.

3. Mereka sudah mulai menganalisis suatu permasalahan dan mengintepretasikannya dengan berbagai cara yang berbeda.

4. Mereka memahami pola pikir seorang wirausaha.

5. Adanya antusias para santri untuk bisa menciptakan suatu usaha.
Luaran yang dapat dicapai dalam pelaksanaan kegiatan ini dapat dilihat melalui contoh materi dan juga foto-foto kegiatan yang dilakukan disana.

\section{Materi Pelatihan}

Materi yang dibuat disajikan dalam bentuk yang sederhana dan sejelas mungkin untuk mencegah peserta merasa bosan dan mengantuk. Materi disajikan dalam bentuk pemahaman melalui permainan yang menarik. Bentuk pelatihan yang dilakukan ingin melibatkan pada santri melalui visual, pendengaran, dan praktek langsung sehingga penerapan materi akan lebih maksimal. Berikut ini adalah beberapa contoh materi yang dipresentasikan dalam pelatihan yang terdiri dari dua materi yaitu materi tentang literasi berpikir kreatif dan kewirausahaan masif.

Gambar 3. menunjukkkan proses interaksi antara pelatih dan peserta mengenai literasi berpikir kreatif. Tema-tema yang dibuat pada materi pelatihan dibuat untuk bisa menstimulus pemikiran mereka serta mengetahui posisi dari kemampuan berpikir kreatif dari para santri. Salah satu contoh metode ketika pelatihan untuk mengetahui sejauh mana kreativitas mereka yaitu melalui permainan menggambar. Mereka hanya diperintah menggambar tetapi tidak mengetahui maksud tersembunyi yang dilakukan dari gambar mereka itu. Setelah mereka menyelesaikan gambarnya barulah dibahas secara bertahap maksud dari permainan yang telah mereka buat. Hasil dari permainan ini, anak mulai terlihat menyadari pola-pola lama yang tanpa mereka sadari sudah menjadi suatu kebiasaan. Dan ternyata secara tidak langsung
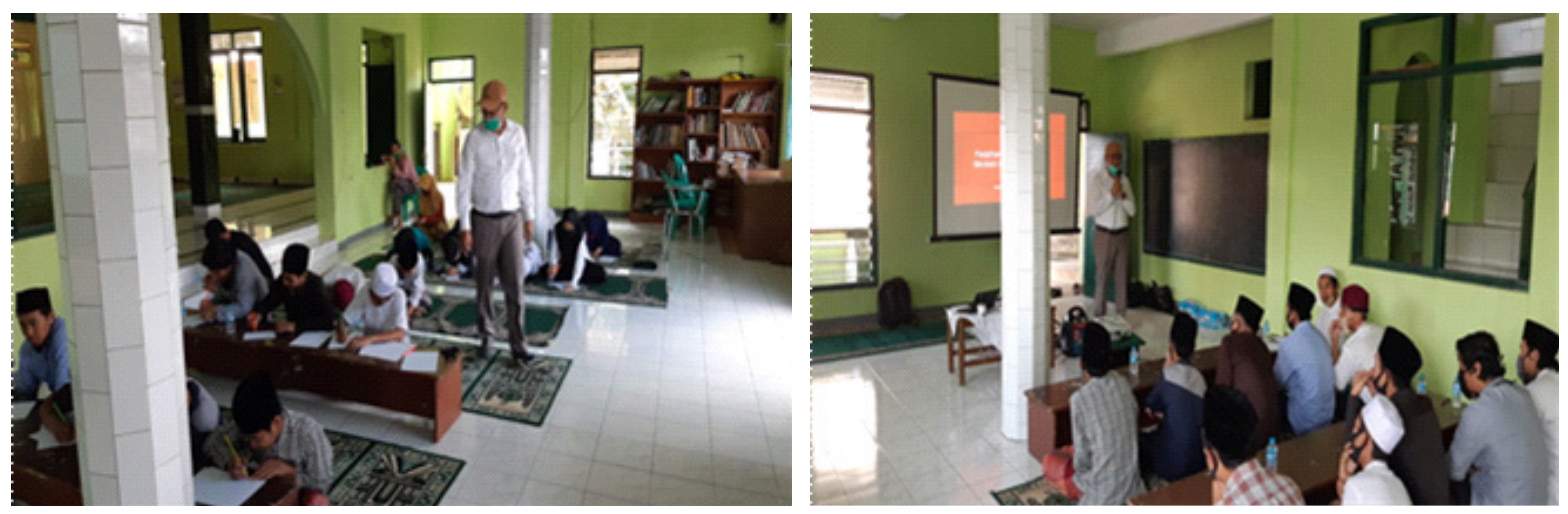

Gambar 3. Pelatihan dan Permainan Literasi Berpikir Kreatif 
sudah mereka terapkan dari mulai jenjang sekolah dasar kecil sampai sekarang. Melalui Pembuktian yang masuk akal dan dapat dicerna oleh para santri, maka akan lebih tertanam maksud dari materi yang ingin diberikan. Pola yang sama juga dilakukan yaitu melalui permainan, ketika pemateri ingin memberikan pemahaman mengenai bagaimana bentuk dari berpikir kreatif dan bagaimana menerapkan pendekatan, untuk berpikir kreatif dengan permainan yang beragam.

Gambar 4. adalah contoh interaksi ketika santri diberikan materi kewirausahaan masif. Materi kewirausahaan masif ini merupakan materi untuk pertemuan kedua. Ketika proses pelatihan awal dijelaskan terlebih dahulu mengenai kewirausahaan dan para santri terlihat tidak terlalu tertarik dibandingkan dengan pertemuan pertama yang membahas tentang berpikir kreatif., Tetapi ketika sudah masuk ke slide power point berikutnya, mengenai materi yang mengkaitkan dengan analogi yang sesuai dengan zaman mereka dan beberapa hal yang menjadi tren pada saat itu, para santri mulai terlihat antusias. Mereka mulai terlihat senang ketika sudah memasuki tema yang disajikan dalam bentuk permainan. Pelatihan yang kedua ini, memfokuskan pentingnya kerja sama tim karena semua permainan yang ada disajikan secara berkelompok. Tugas dari permainan yang sudah mereka kerjakan harus dipresentasikan secara bergantian yang mewakilinya, sehingga setiap santri harus mampu untuk berbicara dan mengemukakan pendapatnya di depan temantemannya.

\section{SIMPULAN}

Rangkaian kegiatan yang dilaksanakan Pesantren Miftahul Jannah disimpulkan bahwa materi yang diberikan sesuai dengan minat para santri, terutama bagi pelajar muda yang memiliki rasa ketertarikan yang tinggi, ini terlihat dari hasil pengisian indikator oleh para santri dan juga hasil pengamatan dari tim pengabdian dan pemateri. Dalam jangka waktu satu minggu para santri sudah mulai mencoba menerapkan pola berpikir kreatif ketika mereka belajar pada saat diajarkan oleh para pengajar di lingkungan pesantren. Sudah ada beberapa santri yang sudah mulai mendapatkan ide untuk mengembangkan suatu produk dan juga tertarik untuk menjadi wirausaha, walaupun sebagian besar masih ragu-ragu. Salah satu faktor penting keberhasilan dalam pelaksanaan pelatihan yaitu penyesuaian dari materi yang akan diberikan sesuai dengan karakteristik dari peserta pelatihan. Sehingga survei yang dilakukan sebelumnya dan adaptasi materi, serta penyesuaian pola penyampaian merupakan faktor kunci dalam pelatihan ini. Dari hasil kegiatan juga terlihat bahwa para santri sebenarnya memiliki ide kreatif yang beragam sehingga akan lebih baik lagi jika dilakukan suatu bimbingan untuk mempertajam nalar mereka. Hal lain yang didapat adalah permainan yang diberikan sangat membantu terutama untuk merangsang mereka untuk bisa memahami materi dan maksud dari materi yang sudah dipersiapkan. Diharapakan para santri ini memang mendapatkan program yang berkesinambungan agar bisa melahirkan para santripreneur yang handal. Katerbatasan dalam pengabdian ini yaitu waktu pelatihan masih kurang dan permainan menarik ruang geraknya
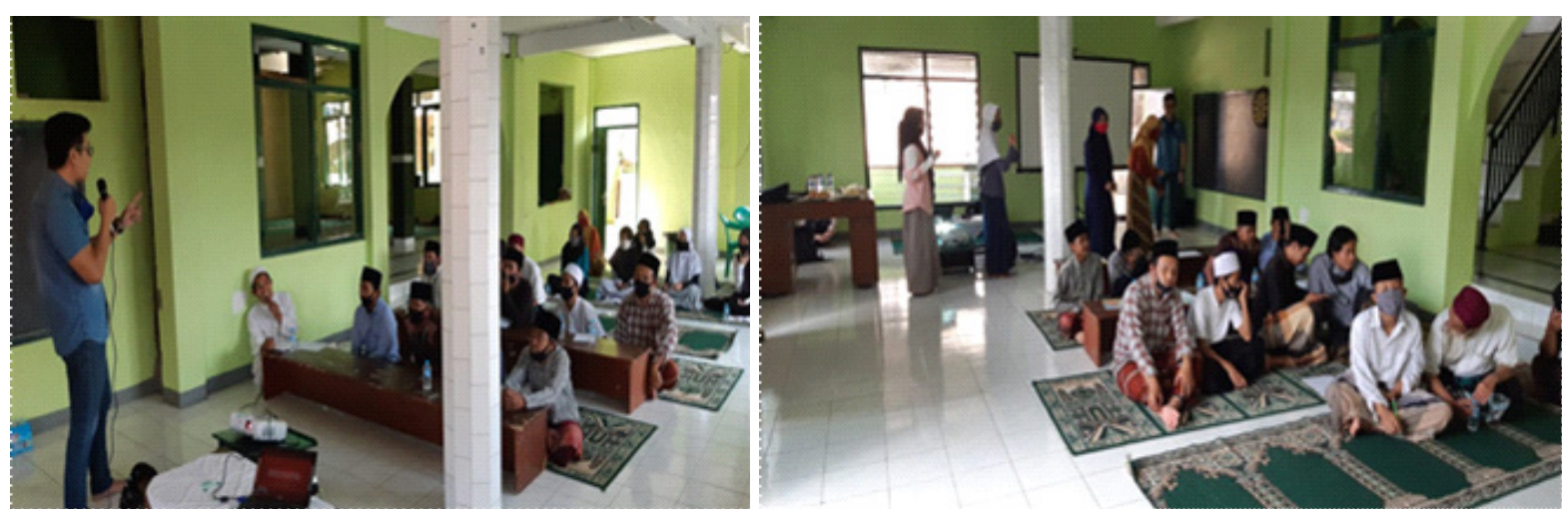

Gambar 3. Contoh Materi Pelatihan Kewirausahaan 
terbatas karena kondisi pada masa pandemi. Sehingga untuk pengabdian selanjutnya membutuhkan penambahan waktu kunjungan dan lebih baik lagi jika ada pendampingan. Selain itu dibutuhkan teknik alternatif penyampaian materi yang menarik ketika dalam kondisi pandemi seperti saat ini.

\section{PERSANTUNAN}

Terima kasih kepada Sekolah Tinggi Ilmu Ekonomi (STIE) Ekuitas yang telah menyediakan fasilitas dalam pelaksanaan kegiatan pengabdian kepada masyarakat melalui Hibah Internal. Kami juga mengucapkan terima kasih kepada Pesantren Miftahul Jannah yang telah berkenan menjadi mitra dalam pengabdian kali ini.

\section{REFERENSI}

Black, C., Freeman, C., \& Stumpo, G. (2015). Conceptual Model and Strategies for Creative Thinking in Apparel Design. International Journal of Fashion Design, Technology and Education, 8(2), 131138. https://doi.org/10.1080/17543266.2015.1018958

Craft, A. (2003). Creative Thinking in the Early Years of Education. Early Years, 23(2), 143-154. https:// doi.org/10.1080/09575140303105

Cropley, A. J. (2000). Defining and Measuring Creativity: Are Creativity Tests Wusing? Roeper Review, 23(2), 72-79. https://doi.org/10.1080/02783190009554069

Estrada, C. A., Isen, A. M., \& Young, M. J. (1994). Positive Affect Improves Creative Problem Solving and Influences Reported Source of Practice Satisfaction in Physicians. Motivation and Emotion, 18(4), 285-299. https://doi.org/10.1007/BF02856470

Fernández-Abascal, E. G., \& Díaz, M. D. M. (2013). Affective Induction and Creative Thinking. Creativity Research Journal, 25(2), 213-221. https://doi.org/10.1080/10400419.2013.783759

Heilbrunn, S. (2010). Advancing Entrepreneurship in An Elementary School: A Case Study. International Education Studies, 3(2), p174. https://doi.org/10.5539/ies.v3n2p174

Hong, E., \& Milgram, R. M. (2010). Creative Thinking Ability: Domain Generality and Specificity. Creativity Research Journal, 22(3), 272-287. https://doi.org/10.1080/10400419.2010.503535

Kirkpatrick, D. (1996). Great Ideas Revisited. Techniques for Evaluating Training Programs. Revisiting Kirkpatrick's Four-Level Model. Training and Development, 50(1), 54-59.

Lyubomirsky, S., King, L., \& Diener, E. (2005). The Benefits of Frequent Positive Affect: Does Happiness Lead to Success? Psychological Bulletin, 131(6), 803-855. https://doi.org/10.1037/00332909.131.6.803

Plucker, J., \& Zabelina, D. (2009). Creativity and Interdisciplinarity: One Creativity or Many Creativities? ZDM, 41(1-2), 5-11. https://doi.org/10.1007/s11858-008-0155-3

Sani, R. (2014). Pembelajaran Saintifik untuk Implementasi Kurikulum 2013. Jakarta: Bumi Aksara.

Santrock, J. W. (2011). Psikologi Pendidikan (2nd ed.). Jakarta: Kencana Prenada Media.

Susanto. (2013). Teori Belajar dan Pembelajaran di Sekolah Dasar. Jakarta: Prenadamedia Group. 